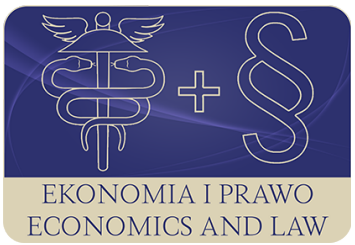

EKONOMIA I PRAWO. ECONOMICS AND LAW

Volume 18, Issue 3, September 2019

p-ISSN 1898-2255, e-ISSN 2392-1625

www.economicsandlaw.pl

ORIGINAL ARTICLE

received 21.01.2019; revised 31.07.2019; accepted 30.09.2019

Citation: Ciak, J.M. \& Gruszczyńska, A. (2019). Goods and services tax in the tax systems of selected countries of the European Union: a case study. Ekonomia i Prawo. Economics and Law,

18(3): 269-282. doi:10.12775/EiP.2019.019.

\title{
Goods and services tax in the tax systems of selected countries of the European Union: a case study
}

\author{
JOLANTA MARIA CIAK \\ corresponding author \\ WSB University in Toruń, Faculty of Finance and Management, Institute of Finance, \\ ul. Młodzieżowa 31a, 87-100 Toruń, Poland \\ ఐ jolanta.ciak@wsb.torun.pl \\ (D) orcid.org/0000-0003-4864-4692 \\ AGNIESZKA GRUSZCZYŃSKA
}

WSB University in Torun, Faculty of Finance and Management, Institute of Finance, Poland

$\square$ aga.gruszczynska@wp.pl

orcid.org/0000-0003-3373-7546

\begin{abstract}
Motivation: In the face of globalisation and free exchange of goods in the European Union, information regarding the mechanism of the functioning of one of the basic sales taxes requires constant update. Therefore, it is necessary to have knowledge of using VAT in the Polish tax system with respect to solutions implemented and used in the neighbouring countries. Although the European Union aims at harmonisation of tax systems functioning in its countries, differences can still be observed not only in the scales and tax rates.

Aim: The aim of the article is to compare goods and services tax functioning in Poland with selected EU member countries in the years 2007-2017. Particular emphasis is put on regulations concerning tax functioning as well as current rates in selected European Union countries i.e.: Germany and Great Britain, and Poland and Lithuania, also the role of the tax in the budget revenue system is presented.

Results: Countries with stabilised economies (Great Britain and Germany) are characterised by less dynamic changes of tax rates, of the tax revenue structure or of tax revenue amount in relations to GDP. They are also characterised by a significant increase in rev-
\end{abstract}


enue due to goods and services tax, but by a simultaneous smaller contribution in total tax revenue. Countries with developing economies in contrast (Poland and Lithuania) are characterised by significant dynamics, which was particularly visible during the world economic crisis. The contribution of goods and services tax in the tax revenue structure is higher, as are this tax rates.

Keywords: goods and services tax; tax and tax system; harmonisation of tax and tax systems JEL: H25; H71; H2

\section{Introduction}

The European Union needs unified law in order to use common standards. It is also visible in tax law including goods and services tax. The processes of harmonising the VAT system of the European Union started as early as in the 1960s, when first directives regarding this were issued. The first Council Directive 67/227/EEC of April 11, 1967 on the harmonisation of legislation of Member States concerning turnover taxes was issued. On that basis the member countries of EEC abandoned the multi-stage system of calculating turnover taxes. It was replaced by consisting of many stages value added tax, that is VAT (Kuraś, 2009, pp. 122-126).

The Sixth Council Directive 77/388/EEC of May 17, 1977 on the harmonisation of legislation of Member States concerning turnover taxes was another document important for the harmonisation of legislation. Work towards a common system of VAT in the member states resulted from this directive. Concepts such as object of the tax, subject of the tax or tax basis were defined (Lipniewicz, 2010, pp. 19-21).

It was of particular importance at the moment of dismantling of customs borders, and new concepts were introduced on January 1, 1993. The term of transport was replaced by intra-Community supply of goods, and import was replaced by intra-Community acquisition of goods. Moreover, the rule of VAT taxation in the country of destination of goods was adopted. Thereby, the tax was required in the place of the final consumption of goods. It must be added that the rule remains applicable, but new solutions are searched for (Lipniewicz, 2010, p. 20).

The aim of the article is to compare the goods and services tax functioning in Poland with selected EU member countries in the years 2007-2017. Particular emphasis is put on regulations concerning tax functioning as well as current rates in selected European Union countries i.e.: Germany and Great Britain, and Poland and Lithuania, also the role of the tax in the budget revenue system is specified.

By no means is the choice of the countries accidental. Germany and Great Britain were selected as they are the biggest economies of the European Union, whose combined EU GDP amounted to 37.1\% (21.1\% Germany and 16.0\% Great Britain respectively) in 2016, and Germany is Poland's closest neighbouring 
country. When it comes to Lithuania, apart from it being Poland's neighbour as well, both countries manifest similar economic and political interests.

\section{Literature review}

The source literature in the area of VAT is considerably limited with respect to the growing popularity of the discussed tax, as it focuses on comments on newly introduced tax provisions, judicature and interpretations in the tax law functioning in a given country (Krywan 2019; Matarewicz 2017; Michalik 2018; Mucha \& Dasiewicz, 2017), or additionally, in methodology of fiscal offences (Turaliński, 2017). Moreover, annual reports of the European Commission (2017), which specify current tax rates and exemptions applied in a given year, constitute a rich source of knowledge in the area of VAT in the European Union. PricewaterhouseCoopers Worldwide Tax Summaries. Corporate Taxes and Deloitte reports - Corporate Tax Rates: International Tax include comparisons of currently applicable provisions concerning VAT in the European Union countries.

However, the subject of VAT in relation to the European Union has been discussed in numerous publications. For example, Agha \& Haughton (1996, pp. 303-308) claim that there is a positive correlation between the age of a VAT system in one country ${ }^{1}$ and the increase in tax revenue, thus the European Union could constitute a good subject of a similar examination, since different countries joined the EU at different moments. Therefore, it would be possible to find a connection between the number of years since a given country joined the EU and the actual VAT rate.

Attention should be drawn to the publication of Bird \& Leon (2006), in which the authors convince that a country must possess an ability to manage VAT appropriately. They also claim that even if the existing VAT rates are increased by the government, it does not necessarily imply a proportional increase in revenue; nevertheless, this way, most beneficial economically, leads to such an increase in developing countries and countries in transition. The authors also note that excessive expansion of VAT in developing countries can discourage market participants through excessive formalisation. In their macro study, Keen \& Lockwood (2010, pp. 138-151) define VAT as 'a money making machine' as a more efficient and effective source enabling countries to generate more revenue, which also compensates for the loss of revenue resulting from lower tariffs in the case of trade liberalisation.

In some publications, authors analyse and evaluate tax policies of the EU countries in the context of public revenue of the EU countries towards economic fluctuations (Owsiak, 2016). The necessity to search for optimal solutions preventing tax evasion, emphasised in the face of the global economic crisis, can be found in the publications of Gemmell \& Hasseldine (2012, pp. 203-231). James (2015) claims that the difficulty of explaining the increase of VAT in rela-

\footnotetext{
${ }^{1}$ Understood as a number of years since its introduction till now.
} 
tion to its real value constitutes the lack of an appropriate regard of the process of creating tax policy, which results in 'real' VAT.

\section{Research methods}

The following research methods are used in the article: an evaluation of scientific and legal achievements in connection with the functioning of goods and services tax, and an analysis of source literature and legal acts of the European Union and the countries selected for evaluation (Poland, Lithuania, Germany and Great Britain). Additionally, an analysis of the contribution of VAT in the structure of budget revenue of those countries and the relation to GDP was conducted. The statistical data come from Eurostat.

\section{The principles of goods and services tax in Poland}

Before Poland entered the structures of the European Union, systematic work was conducted on the VAX system and its harmonisation in the member countries. After the country signed the European Agreement establishing an association between Poland and the European Communities in 1991, in the country efforts were undertaken to approximate the legislation to the Community legislation, which was required by the Association Agreement. The work conducted on the national tax system resulted in introducing VAT on July 5, 1993 (Lipniewicz, 2010, p. 20).

VAT rates are regulated in the following way. $5 \%$ is the minimum, not reduced VAT rate, which results from the European Union regulations adopted in Poland as well. It is specified in the Directive of the Council of the European Union no. 2006/112/EC. The European Union has not established the upper limit of the VAT rate. The standard VAT rate in Poland applicable from January 1, 2011 to the end of 2018 is $23 \%$. It results from Act on Value Added Tax (2004, article 146a).

Generally, the applicable VAT rates can be classified as follows:

- standard VAT rate: $22-23 \%$ - currently the rate of 22\% applies, but from lst January 2011 to 31st December 2018 the rate of 23\% applies.

- reduced rates:

- the rate of 7 or $8 \%$ - essentially it is the rate of 7\%, but from lst January 2011 to 31st December 2018 the rate of $8 \%$ applies,

- the rate of $5 \%$.

- the rate of $0 \%$ - equivalent to exemption, but it is not the same as exemption, as it is the basis for tax deduction (Act on Value Added Tax, 2004, article 41, paragraphs 1-6).

The standard VAT rate of $23 \%$ is generally applied to the supply of all goods and services except those covered by specific provisions concerning VAT.

A reduced rate of $8 \%$ applies to supplies which include among others supplies of pharmaceutical products, passenger transport services and supplies 
of goods for the Social Housing Programme. A reduced rate of 5\% applies to books and magazines, to unprocessed and basic food, also to seeds in the case of farming. The services exempt from VAT include among others selected financial, insurance and educational services.

The reporting period for VAT is one calendar month. VAT returns should be submitted by the 25th of the month following the accounting period. The legislation obligates goods and services tax payers (except those exempted from VAT) to keep computer records of all data required to fill in tax returns and additional information provided with a VAT return (Act on Value Added Tax, 2004, article 103). It should be mentioned that since January 1,2017 the option of quarterly VAT returns has been impossible for most taxpayers. Quarterly VAT returns are no longer possible in the case of new enterprises (entitled to such settlements in the first year of their activity) and companies with turnover of over EUR 1.2 million. The new regulation is also applicable for taxpayers registered after September 30, 2016 (PwC, 2017, p. 567).

Moreover, since January 1, 2018 micro entrepreneurs are obligated to keep electronic register of VAT on all purchases and sales and send it in the form of a Unified Control File JPK_VAT. Big enterprises have sent a Unified Control File since July 1, 2016, small and middle-sized enterprises since January 1, 2017. A Unified Control File is not sent in the following cases:

- subjective exemptions - sales of goods and services exempt from VAT in accordance with Act on Value Added Tax (2004, article 43, paragraph 1);

- objective exemptions - turnover of a company was not higher than PLN 200000 in accordance with Act on Value Added Tax (2004, article 113, paragraph 1 or 9 );

- execution of public tasks by International organisations in accordance with Act on Value Added Tax (2004, article 82, paragraph 3) (Ministry of Finance of Poland, 2018).

Revenue from VAT constitutes an important source of income for the state budget in Poland, hence the above actions aiming at sealing up VAT regulations.

\section{Goods and services tax in Germany}

The German VAT legislation dates from 1980s, when in 1979 the Act on Goods and Services Umsatzsteuergesetz (UStG) was passed. Now the act of March 11, 2004 is and sales tax guidelines Umsatzsteuer-Richtlinien (UStR) there are introduced in tax regulations' in 2018.

It should be noted that VAT functions in Germany under two names. In German tax regulations Umsatzsteuer (Ust) is used, but in accounting documents Mehrwersteuer (MwSt) is found (Jagłowski, 2017, p. 8). In the case of a conflict between the German VAT Act and the EU directives, the latter prevail. Moreover, in Germany an import value added tax Einfuhrumsatzsteuer regulated by the above Act is applied. 
In Germany revenue from sales of goods and services within the framework of common system of the European Union is subject to VAT at one of the two rates: a standard rate of $19 \%$ and a reduced rate of $7 \%$ used for instance for food, magazines, books and transport services (PwC, 2017, p. 222).

Based on the data of Eurostat and the reports of the European Commission, it can be noted that in Germany, one of very few European Union countries, no changes in the VAT rates have been introduced in the last decade. The observed changes concerned a number of exemptions in terms of a reduced rate. The majority of goods and services are taxed with the standard rate. A reduced rate is used particularly for supply, import and intra-Community acquisition of almost all foodstuffs except drinks and food supply. It concerns for instance local transport, supply of books, newspapers and magazines and certain works of art.

VAT is administered by the relevant tax office. The system of evaluation of tax amount is based on preliminary tax returns submitted every month or quarter by the tenth day of the following month. Monthly tax returns are acceptable only for new enterprises or when VAT amounted to over EUR 7500 in the previous year. Moreover, returns are drawn up on the basis of actual transactions in a given period identified in account books. A constant prolongation of a return is accessible for an advance amounting to one eleventh of overall tax due in the previous year. Otherwise payment is due after a return is submitted. A taxpayer is usually entitled to deducting tax on expenditure from tax due on production (PwC, 2018a, pp. 222-223).

In accordance with the law, VAT is an annual tax. Every taxpayer is supposed to submit an annual tax return for each calendar year regardless of an actual determined financial year of a company. A VAT return is submitted with a company tax return and a business activity tax, and the annual rate of return must equal the sum of monthly or quarterly returns (PwC, 2018a, p. 754). Monthly or quarterly VAT returns must be sent by electronic mail with the use of ELSTER system to the relevant tax office. The same applies to annual VAT returns, which must be supplied by the end of May in the following year. It is also required to submit financial returns confirming return (PwC, 2018a, p. 764).

Apart from VAT returns, companies can also be obligated to submit additional Intrastat German statistical information and EC sales list or a summary (Amavat, 2018).

In terms of revenue, VAT constitutes one of the most important taxes in Germany. Taking a single tax rate into consideration, the current VAT system requires all goods and services to be subject to the same tax when they reach the final consumer. The amount of tax due shall equal the rate for delivered goods and services. The number of stages in the process of production or distribution of goods and services delivered to the consumer is irrelevant (European Commission, 2018). 


\section{Goods and services tax in Great Britain}

The VAT system was introduced in Great Britain in 1973. The VAT Act of 1994 (as amended) bases on the EU regulations concerning VAT and establishes rules for the British VAT registration, compliance, returns, Intrastat, EC sales list and other relating issues. The British VAT system is served by HM Revenue and Customs (HMRC) (Avalara VATlive, 2018).

In Great Britain the sale of goods and supply of services are subject to VAT according to the following rates:

- standard raste of $21 \%$ since 2011 ;

- reduced rates of 5\% and 0\% (European Commission, 2017, p. 21).

Most goods and services in Great Britain are taxed with the standard rate of $20 \%$. The reduced rate concerns installation of energy saving materials in all houses and some installations of heating appliances financed with grants, some housing investments and renovations, also sale of children's car seats. The $0 \%$ rate concerns among others the majority of food, clothes and footwear for small children, all kinds of documents, building of new flats, passenger transport, also drinking water and some pharmaceuticals.

Certain supplies are exempt from tax and the main categories include certain participations in land, insurance, financial services, healthcare and social care.

VAT returns must be submitted in established usually three-month intervals. Bigger companies may be obligated to submit monthly returns or to execute monthly payments on account. Taxpayers not exceeding the turnover of GBP 1.35 million can decide on annual returns, but they are obligated to pay monthly VAT liabilities and settle the balance at the end of each year (European Commission, 2018). Since April 1, 2012 all companies are obligated to submit VAT returns and make electronic payments (PwC, 2013, p. 2120).

Apart from VAT returns, companies may be obligated to submit additional statistical information. The British Intrastat system (or an additional statistical declaration) requires a monthly return with a list of all movements of goods between Great Britain and other European Union countries. An EC sales list return includes information on VAT identification numbers of customers in the EU and values of sales in a given period of time and it must be submitted quarterly or monthly depending on turnover (Ministry of Finance of Great Britain, 2018).

\section{Lithuanian rules of goods and services tax}

The law introducing the value added tax in Lithuania was passed by the Parliament of the Republic of Lithuania on December 22, 1993 and it was in force from May 1, 1994 to June 30, 2002. It was replaced by the IX-751 Law on Value Added Tax of March 5, 2002 (Ministry of Finance of the Republic of Lithuania, 2018). Since May 1, 2004 the Lithuanian Law on VAT has been pursuant to the sixth Council Directive (European Commission, 2018). Therefore, all rules concerning Lithuanian registrations, and returns are based on the EU 
directives on VAT. The tax is managed by the State Tax Inspectorate (STI) subordinate to the Ministry of Finance of the Republic of Lithuania.

Revenue from the sale of goods and services in Lithuania within the common European Union system is subject to VAT according to the following rates:

- standard rate of 21\% applied since 2010 (European Commission, 2017, p. 21);

- reduced rates of 9\% and 5\% (State Tax Inspectorate Under the Ministry of Finance of the Republic of Lithuania, 2018);

- zero rate of VAT (an exemption with the right to deduct) is used for export of goods, intra-Community supply of goods, and also certain other supplies and intra-Community purchase of goods and services specified in the VAT Act (European Commission, 2018). In order to use the zero rate of VAT, taxpayers need to keep transport documentation to prove that goods are actually in the intra-Community trading (PwC, 2018b)

In order to ensure the compliance with the VAT Law, Lithuanian taxpayers are obligated to submit a monthly VAT return and pay VAT to a tax office. In the case of supplying goods or services to other EU member countries, a EC sales list should be submitted with a VAT return. Apart from the above mentioned requirements of VAT reporting, since October 1, 2016 all VAT taxpayers (including foreign companies registered in Lithuania for VAT purposes) are obligated to send monthly invoice reports to the Lithuanian tax office ( $\mathrm{PwC}$, 2018a, p. 29).

It is obligatory to submit a VAT return and also pay VAT due by the 25th day after the accounting period. The following accounting periods are applicable in Lithuania:

- a calendar month - for legal persons, but in the cases when turnover did not exceed EUR 60000 (LTL 200000 till 2015) in the previous calendar year, a legal person has the right to demand a six-month tax period;

- a calendar half year - in the case of natural persons being taxpayers, whereby they can declare a monthly accounting period without income limitations;

- other accounting period - a legal person or a foreign taxpayer can choose an accounting period other than a calendar month on condition that it does not exceed 60 days: the beginning of a fiscal year and the end of the last tax period of a VAT taxpayer must correspond to the beginning and end of a calendar year, as long as such an accounting period is more suitable for a taxpayer on account of the nature of financial accounting used by a taxable foreign parent company (State Tax Inspectorate Under the Ministry of Finance of the Republic of Lithuania, 2018).

Revenue from VAT constitutes a source of budget revenue in Lithuania. Analysing the changes of the Lithuanian value added tax rate in the last decade, an economic slowdown can be observed, which started as early as in 2008, when credit conditions considering building investments in particular were tightened. The Lithuanian financial economy collapsed when the global financial crisis started, which resulted in numerous reforms, including among others raising 
the basic rate of VAT from $18 \%$ to $19 \%$ in 2009 and from $19 \%$ to $21 \%$ in the following year (Kloc-Konkołowicz et al., 2015, p. 11).

\section{Vat rates in selected European Union countries and their role in the budget revenue in the years 2007-2017: results of the study}

For transparency purposes the compared VAT rates in Germany, Lithuania, Poland and Great Britain applied in the last 11 years are presented in two separate parts of table 1 .

Analysing table 1, the following can be stated:

- Germany as the only country (among the analysed ones) has not changed the applied rates, in Lithuania the reduced rates have been kept;

- only in Great Britain reduction of the tax rate has been introduced in the last 11 years;

- Poland and Lithuania have used the possibility of using two reduced rates in the whole examined period of time;

- among the analysed member states, Poland has applied the highest standard VAT rates.

The changes in the levels of VAT rates are presented below. Considering the big amount of data, chart 1 presents only standard rates applied in the examined period in Great Britain, Germany, Lithuania and Poland.

It should be noted that since 2011 all the four examined countries have maintained a constant standard VAT rate. The German VAT rate is currently the lowest, despite the fact that initially Lithuanian and British standards were the lowest. Considerable disproportions in rates occurred in 2009, when the difference for instance between the lowest British and the highest Polish rates amounted to 7 percentage points.

Analysing table 2 it can be noted that the contribution of Lithuanian VAT revenue in relation to the total tax revenue was the highest in the whole examined period (26.9\% on average). The lowest contribution of VAT, excluding the years 2008-2010, can be seen in the German budget (17.7\% on average). It was also noted that until 2010 a clear division occurred - the contribution of Polish and Lithuanian VAT revenue exceeded the German and British revenue (in Great Britain an average percentage of VAT in tax revenue amounted to $19.1 \%$, in Poland it amounted to $22.8 \%$ ).

It can be said that Germany has the most static course of annual tax revenue in terms of total tax revenue in the examined period. The most considerable dynamics of changes until 2011 can be observed in Lithuania and Great Britain, but in Poland in the years 2011-2016. At the same time, from 2012 the most consistent values were noted in Poland and Great Britain. After 2012 the presented contribution of VAT in total budget revenue for Lithuania was considerably different from the values in the other examined member countries - the differ- 
ences amount to 5 percentage points for Poland, 6.8 percentage points for Great Britain and 9.7 percentage points for Germany on average.

The analysis of table 3 indicates that in the whole examined period, an average contribution of VAT revenue to GDP for the whole EU-28 amounted to $6.84 \%$. Lower values than EU-28 occurred in Great Britain $(6.39 \%$ on average), and in the other examined countries they exceeded 7\% of GDP $(7.65 \%$ of GDP in Germany, 7.70\% of GDP in Lithuania, 7.45\% of GDP in Poland respectively).

\section{Conclusion}

VAT constitutes an essential source of revenue for the state budget, which enforces using more and more advanced mechanisms of tax audit. Considering abuses in the activity of so called grey market and publicised in the last years uses of carousel mechanisms, the activities of legislators seem to be a logical consequence. Different types of electronic returns, international sale lists or the obligation to send detailed bases with descriptions of transactions between enterprises and settlements between contractors are an example (JPK, Instrast, etc.).

Despite the fact that the European Union aims at harmonisation of tax systems in its member countries, differences can still be seen. The selected information presented in the article on the functioning of goods and services tax in selected European Union countries - concerning mainly currently applied rates, accounting periods, deadlines for tax returns or turnover criterion for taxpayers - shows the ongoing changes resulting from the process of VAT harmonisation in the European Union. It also indicates the necessity to continue simplifying procedures in the free market of intra-Community exchange.

In all the examined countries, the functioning of VAT is regulated by acts, in each of those countries both standard and reduced tax rates are applied. Only Germany has not changed the rates, in Lithuania a constant level of reduced rates is noticed. In the period of the examined 11 years only in Great Britain a reduction of rates was used. On the other hand, Poland and Lithuania used the possibility of using two reduced rates in the whole examined period. It should also be emphasised that among the selected for analysis member countries, the highest standard rates of goods and services tax were applied in Poland. When it comes to the contribution of VAT in tax revenue of the examined countries, it was different. In Germany the contribution basically did not exceed $17.7 \%$ on average, in Poland and in Lithuania it amounted to $22.8 \%$ and $26.9 \%$ respectively.

The extent and multi-layered structure of the discussed topic made the authoresses focus on a few selected issues only, which does not exhaust the topic. The authoresses hope the article will lead to further discussion and in-depth studies in this area. 


\section{References}

Agha, A., \& Haughton, J. (1996). Designing VAT systems: some efficiency considerations. The Review of Economics and Statistics, 78(2). doi:10.2307/2109932. Amavat. (2018). Overview German VAT. Retrieved 25.11.2018 from https://amavat.eu.

Avalara VATlive. (2018). UK VAT. Retrieved 28.11.2018 from https://www.avalara.com.

Bird, R.M., \& Leon, P.P. (2006). Is VAT the best way to impose a general consumption tax in developing countries? International Studies Program Working Paper, 06-18.

European Commission. (2017). VAT rates applied in the member states of the European Union. Retrieved 25.11.2018 from https://ec.europa.eu.

European Commission. (2018). Taxation and customs union. Retrieved 21.11.2018 from http://ec.europa.eu.

Eurostat. (2018). Retrieved 25.11.2018 from http://appsso.eurostat.ec.europa. eu.

Gemmell, N., \& Hasseldine, J. (2012). The tax gap: a methodological review. In T. Stock (Ed.), Advances in taxation. Bingley: Emerald.

Jagłowski, M. (2017). Niemiecki VAT (Umsatzsteuer) $i$ inne obowiazki podatkowe polskich firm działających na rynku niemieckim. Ruciane-Nida: Emirat.

James, K. (2015). The rise of the Value Added Tax. Cambridge: Cambridge University Press. doi:10.1017/CBO9781107358522.

Keen, M., \& Lockwood, B. (2010). The Value Added Tax: its causes and consequences. Journal of Development Economics, 92(2). doi:10.1016/j. jdeveco.2009.01.012.

Kloc-Konkołowicz, M., Marnic, A., \& Stążka-Gawrysiak, A. (Eds.). (2015). Przygotowania Litwy do cztonkostwa $w$ strefie euro i pierwsze doświadczenia zwiąane z wprowadzaniem wspólnej waluty. Retrieved 25.11.2018 from https://www.nbp.pl.

Krywan, T. (2019). VAT 2019. Warszawa: Infor.

Kuraś, Z. (2009). Harmonizacja systemów podatkowych państw członkowskich Unii Europejskiej. Studia Gdańskie, 6.

Lipniewicz, R. (2010). Docelowy system VAT w Unii Europejskiej: harmonizacja opodatkowania transakcji wewnątrzwspólnotowych. Warszawa: Wolters Kluwer.

Matarewicz, J. (2017). Ustawa o podatku od towarów i ustug VAT: komentarz. Warszawa: Wolters Kluwer.

Michalik, J. (2018). VAT: komentarz. Warszawa: CH Beck.

Ministry of Finance of Great Britain. (2018). How to report your EU sales for VAT. Retrieved 14.11.2018 from https://gov.uk.

Ministry of Finance of Poland. (2018). Jednolity plik kontrolny. Retrieved 18.11.2018 from https://www.podatki.gov.pl.

Ministry of Finance of the Republic of Lithuania. (2018). Retrieved 14.11.2018 from https://finmin.Irv.lt. 
Mucha, M., Dasiewicz, S. (2017). VAT 2017: komentarze do zmian, ujednolicony tekst ustawy. Warszawa: ODDK.

Owsiak, S. (Ed.). (2016). Polityka podatkowa krajów Unii Europejskiej wobec kryzysu finansowego. Warszawa: PWN.

PwC. (2013). Worldwide tax summaries: corporate taxes 2013/14. Retrieved 25.11.2018 from https://www.pwc.com.

PwC. (2017). Worldwide tax summaries: corporate taxes 2017/18. Retrieved 25.11.2018 from https://www.pwc.com.

PwC. (2018a). Business guide: Lithuania 2018. Retrieved 25.11.2018 from https:// www.pwc.com.

PwC. (2018b). Worldwide tax summaries: Lithuania. Retrieved 28.11.2018 from http://taxsummaries.pwc.com.

State Tax Inspectorate Under the Ministry of Finance of the Republic of Lithuania (2018). Value Added Tax. (2018). Retrieved 17.11.2018 from https:// www.vmi.lt.

Turaliński, K. (2017). Podatek VAT: oszustwa podatkowe, przemyt i zorganizowana przestępczość skarbowa. Warszawa: Artefakt.edu.pl.

Ustawa z dnia 11 marca 2004 o podatku od towarów i usług [Act of 11 March 2004 on Value Added Tax] (Dz.U. 2004 nr 54 poz. 535) (Poland).

\section{Acknowledgements}

Author contributions: authors have given an approval to the final version of the article. Authors contributed to this work equally.

Funding: this research was funded by the WSB University in Toruń sources. 


\section{Appendix}

Table 1.

VAT rates in selected European Union countries in the years 2007-2017 (in \%)

\begin{tabular}{|c|c|c|c|c|c|c|c|c|c|c|c|}
\hline Country & 2007 & 2008 & 2009 & 2010 & 2011 & 2012 & 2013 & 2014 & 2015 & 2016 & 2017 \\
\hline \multicolumn{12}{|c|}{ Standard rates } \\
\hline Germany & 19.0 & 19.0 & 19.0 & 19.0 & 19.0 & 19.0 & 19.0 & 19.0 & 19.0 & 19.0 & 19.0 \\
\hline Lithuania & 18.0 & 18.0 & 19.0 & 21.0 & 21.0 & 21.0 & 21.0 & 21.0 & 21.0 & 21.0 & 21.0 \\
\hline Poland & 22.0 & 22.0 & 22.0 & 22.0 & 23.0 & 23.0 & 23.0 & 23.0 & 23.0 & 23.0 & 23.0 \\
\hline Great Britain & 17.5 & 17.5 & 15.0 & 17.5 & 20.0 & 20.0 & 20.0 & 20.0 & 20.0 & 20.0 & 20.0 \\
\hline \multicolumn{12}{|c|}{ Reduced rates } \\
\hline Germany & 7.0 & 7.0 & 7.0 & 7.0 & 7.0 & 7.0 & 7.0 & 7.0 & 7.0 & 7.0 & 7.0 \\
\hline \multirow{2}{*}{ Lithuania } & 5.0 & 5.0 & 5.0 & 5.0 & 5.0 & 5.0 & 5.0 & 5.0 & 5.0 & 5.0 & 5.0 \\
\hline & 9.0 & 9.0 & 9.0 & 9.0 & 9.0 & 9.0 & 9.0 & 9.0 & 9.0 & 9.0 & 9.0 \\
\hline \multirow{2}{*}{ Poland } & 3.0 & 3.0 & 3.0 & 3.0 & 5.0 & 5.0 & 5.0 & 5.0 & 5.0 & 5.0 & 5.0 \\
\hline & 7.0 & 7.0 & 7.0 & 7.0 & 8.0 & 8.0 & 8.0 & 8.0 & 8.0 & 8.0 & 8.0 \\
\hline \multirow{2}{*}{ Great Britain } & \multirow{2}{*}{5.0} & \multirow{2}{*}{5.0} & \multirow{2}{*}{5.0} & \multirow{2}{*}{5.0} & \multirow{2}{*}{5.0} & \multirow{2}{*}{5.0} & \multirow{2}{*}{5.0} & \multirow{2}{*}{5.0} & \multirow{2}{*}{5.0} & 0.0 & 0.0 \\
\hline & & & & & & & & & & 5.0 & 5.0 \\
\hline
\end{tabular}

Source: Own study based on Eurostat (2018).

Table 2.

Annual revenue from VAT in selected European Union countries in the years 20072016 (in \% of total tax revenue)

\begin{tabular}{|c|c|c|c|c|}
\hline Year & Germany & Lithuania & Poland & Great Britain \\
\hline 2007 & 17.40 & 26.72 & 23.80 & 17.71 \\
\hline 2008 & 17.50 & 25.94 & 23.22 & 16.87 \\
\hline 2009 & 18.20 & 24.13 & 23.26 & 16.12 \\
\hline 2010 & 18.30 & 27.50 & 24.16 & 18.09 \\
\hline 2011 & 18.20 & 28.72 & 24.58 & 19.92 \\
\hline 2012 & 17.90 & 28.03 & 22.24 & 20.27 \\
\hline 2013 & 17.60 & 27.70 & 22.03 & 20.34 \\
\hline 2014 & 17.50 & 27.50 & 22.38 & 20.67 \\
\hline 2015 & 17.50 & 26.72 & 21.61 & 20.69 \\
\hline 2016 & 17.20 & 26.24 & 21.43 & 20.22 \\
\hline
\end{tabular}

Source: Own study based on Eurostat (2018). 
Table 3.

Annual revenue from VAT in selected European Union countries in the years 20072017 (in \% of GDP)

\begin{tabular}{cccccc}
\hline Year & Germany & Lithuania & Poland & Great Britain & EU-28 \\
\hline 2007 & 6.8 & 8.0 & 8.2 & 6.0 & 6.8 \\
2008 & 6.9 & 7.9 & 7.9 & 5.8 & 6.6 \\
2009 & 7.2 & 7.3 & 7.3 & 5.2 & 6.4 \\
2010 & 7.0 & 7.8 & 7.6 & 6.0 & 6.7 \\
2011 & 7.0 & 7.8 & 7.8 & 6.8 & 6.9 \\
2012 & 7.0 & 7.6 & 7.1 & 6.7 & 6.9 \\
2013 & 7.0 & 7.5 & 7.0 & 6.7 & 6.9 \\
2014 & 6.9 & 7.6 & 7.1 & 6.7 & 6.9 \\
2015 & 6.9 & 7.7 & 7.0 & 6.8 & 7.0 \\
2016 & 6.9 & 7.8 & 7.2 & 6.8 & 7.0 \\
2017 & 6.9 & 7.8 & 7.8 & 6.8 & 7.1 \\
\hline
\end{tabular}

Source: Own study based on Eurostat (2018).

\section{Chart 1.}

VAT standard rates in selected European Union countries in the years 2007-2017 (in \%)

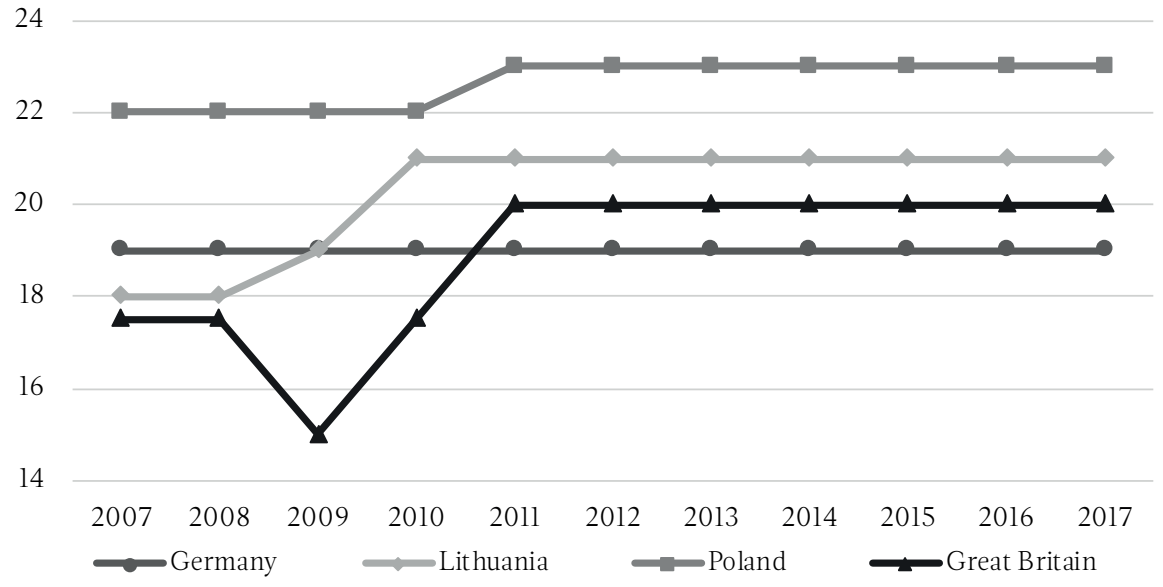

Source: Own study based on Eurostat (2018). 